\title{
PENERAPAN PENDEKATAN METAKOGNITIF UNTUK MENINGKATKAN KEMAMPUAN BERPIKIR KRITIS MATEMATIS SISWA SMA DITINJAU DARI TAHAP PERKEMBANGAN KOGNITIF
}

\author{
${ }^{1}$ Raras Budiarti Lestari, ${ }^{2}$ Hepsi Nindiasari, ${ }^{3}$ Abdul Fatah \\ 1,2,3 Universitas Sultan Ageng Tirtayasa, Jl. Raya Jakarta, Kota Serang, Banten (0254)280330, Indonesia \\ e-mail: rrasrofa1@gmail.com
}

\begin{abstract}
Abstrak
Penelitian ini dilatar belakangi oleh rendah nya kemampuan berfikir kritis matematis siswa SMA. Berdasarkan penelitian relevan sebelumnya menyatakan bahwa kemampuan berpikir kritis mahasiswa calon guru SD hanya sebesar 34,06 persen yang terdiri dari 36,26\% untuk mahasiswa berlatar belakang IPA dan 26,62\% calon guru berlatar belakang non IPA (Maulana, 2008:2). Pendekatan Metakognitif dipilih untuk dapat meningkatkan kemampuan berfikir kreatif siswa SMA ditinjau dari tahap perkembangan kognitif siswa. Populasi penelitian adalah seluruh siswa kelas XI SMA Negeri 6 Pandeglang Tahun ajaran 2017/2018 dan sampel penelitiannya ialah kelas XI IPA 1 sebagai kelas eksperimen dan kelas XI IPA 5 sebagai kelas kontrol yang dipilih secara acak. Penelitian ini bertujuan untuk mengetahui:1. Mengetahui peningkatan kemampuan berpikir kritis metamatis yangdiberikan pembelajaran menggunakan pendekatan metakognitif lebih tinggi daripada pembelajaran ekspositiri; 2. Mengetahui apakah ada pengaruh interaksi antara pendekatan metakognitif dan tahapan perkembangan kognitif terhadap kemampuan berpikir kritis matematis siswa. Hasil penelitian menunjukan : 1. Peningkatan kemampuan berpikir kritis siswa yang diberikan pembelajaran menggunakan pendekatan metakognitif lebih tinggi dibandingkan pembelajaran ekspositori. 2. Terdapat interaksi antara pendekatan metakognitif dan tahap perkembangan kognitif (formal, transisi. konkret) terhadap kemamapuan berpikir kritis matematis siswa.
\end{abstract}

Kata Kunci: Pembelajaran metakognitif, tahap perkembangan kognitif, berpikir kritis

\begin{abstract}
This research is motivated by the low critical thinking skills of high school students. Based on the previous relevant research, it was stated that the critical thinking ability of elementary school prospective students was only 34.06 percent consisting of $36.26 \%$ for students with a natural science background and $26.62 \%$ for nonscience background teachers (Maulana, 2008: 2). Metacognitive approach was chosen to be able to improve the creative thinking skills of high school students in terms of the stages of cognitive development of students. The study population was all class XI Pandeglang 6 High School 2017/2018 academic year and the research sample was XI IPA 1 class as the experimental class and XI IPA 5 class as the randomly selected control class. This study aims to find out: 1 . Knowing the increase in the cognitive critical thinking skills given by learning using the metacognitive approach is higher than expository learning; 2 . Knowing whether there is an interaction effect between the metacognitive approach and the stages of cognitive development on students' mathematical critical thinking abilities. The results of the study show: 1 . Increased critical thinking skills of students given learning using a higher metacognitive approach than expository learning. 2. There is an interaction between the metacognitive approach and the stages of cognitive development (formal, transition. Concrete) to the ability of mathematical critical thinking students.
\end{abstract}

Keywords: Metacognitive learning, the stage of cognitive development, critical thinking

\section{PENDAHULUAN}

Matematika merupakan pelajaran yang sangat penting. Matematika adalah bidang studi yang dipelajari oleh semua siswa dari tingkat Sekolah Dasar (SD) hingga Sekolah Menengah Atas (SMA) dan bahkan Perguruan Tinggi. Banyak orang yang memandang matematika 
sebagai bidang studi yang paling sulit. Meskipun demikian, semua orang harus mempelajarinya karena merupakan sarana untuk memecahkan masalah kehidupan seharihari.

Sulistiani (2016) menyatakan berpikir kritis juga memiliki manfaat dalam jangka panjang, mendukung siswa dalam mengatur keterampilan belajar mereka, dan kemudian memberdayakan individu untuk berkontribusi secara kreatif pada profesi yang mereka pilih.Menurut Maulana (2008) berpikir kritis sangat diperlukan oleh setiap orang untuk menyikapi permasalahan dalam realita kehidupan yang tak bisa dihindari. Dengan berpikir kritis, seseorang dapat mengatur, menyesuaikan, mengubah, atau memperbaiki pikirannya, sehingga ia dapat mengambil keputusan untuk bertindak lebih tepat.

Tetapi pada umumnya disekolah-sekolah belum dibiasakan mengembangkan kemampuan berpikir kritis terutama di sekolah yang saya hendak teliti. Guru lebih cenderung mendorong siswa untuk menjawab soal dengan benar daripada memunculka ide-ide baru atau memikirkan ulang dari kesimpulan-kesimpulan yang sudah ada. Hal ini dapat dilihat dari hasil studi pendahuluan yang dilakukan oleh penelitian yang dilakukan Mayadiana (Maulana, 2008:2), bahwa kemampuan berpikir kritis mahasiswa calon guru SD masih rendah, yakni hanya mencapai 36,26\% untuk mahasiswa berlatar belakang IPA, 26,62\% untuk mahasiswa berlatar belakang non-IPA, serta 34,06\% untuk keseluruhan mahasiswa.

Semua informasi yang ditemukan di lapangantersebut-mengenai rendahnya kemampuan berpikirkritis mahasiswa PGSD — tidak selayaknya dibiarkanbegitu saja. Akan tetapi, perlu kiranya dilakukan sebuahupaya untuk menindaklanjutinya dalam rangka perbaikan,salah satu alternatifnya adalah dengan menerapkansuatu strategi dan pendekatan pembelajaran yang lebihinovatif.Menurut Udi \& Cheng dalam Sulistiani(2016) menegaskan bahwa berpikir kritis harus menjadi dasaryang meresap dari pengalaman pendidikan semua siswa mulai dari pra-sekolah hinggaSMA dan perangkat di universitas serta program terstruktur dalam berpikir kritis harusdimulai dengan mengenalkan karakter (disposisi) yang tepat dan beralih menuju ke pengembangan kemampuan berpikir kritis.

Sumarmo (2010) menyatakan apabila kebisaan berpikir dan sikap seperti diatas berlangsung secara berkelanjutan, maka secara akumulatif akan tumbuh disposisi (disposition) terhadap bidang studinya yaitu keingintahuan, kesadaran, kecendrungan, dan dedikasi yang kuat pada diri siswa untuk berpikir dan berbuat dengan cara yang positif. Merujuk pada pendapat polking (Sumarmo,2010) disposisi matematis menunjukkan (1) rasa percaya diri dalam menggunakan matematis (2) fleksibelitas dalam menyelidiki gagasan (3) 
tekun mengerjakan tugas matematika (4) Minat, rasa ingin tahu dan daya temu dalam melakukan tugas matematik (5) cenderung memonitor, merepleksikan performance dan penalaran mereka sendiri. (6) Menilai aplikasi matematika ke situasi lain dalam matematika dan pengalaman sehari-hari. (7) apresiasi peran matematika dalam kultur dan nilai, matematika sebagai alat dan bahasa.

Menurut Hendriana (2017) disposisi juga merupakan bagian dari soft skills matematis dan Kompetensi dasar Sikap Sosial matematika yang perlu mendapat perhatian guru dalam melaksanakan pembelajarannya. Sesuai pedoman pembelajaran matematika dalam kurikulum 2013 yaitu pembinaan soft skills dan hard skils matematis dilaksanakan secara bersamaan dan berimbang.Dalam penelitian ini hards skill yaitu kemampuan berpikir kritis dan soft skills yaitu disposisi berpikir kritis matematis. Tetapi dalam hal ini siswa yang memiliki disposisi tinggi akan lebih gigih, tekun, dan berminat mengmbangkan pengetahuannya. Dengan pengetahuan ini, siswa dapat memiliki kemampuan berpikir kritis. Dengan demikian disposisi matematis merupakan prasyarat yang menunjang pengembangan kemampuan berpikir kritis matematis.

Mengingat pentingnya disposisi matematika demi keberhasilan dalam pembelajaran matematika maka kemampuan disposisi matematis juga perlu dikembangkan. Tetapi disekolah disposisi kritis matematis masih kurang dikembangkan Hal ini sama dengan yang disebutkan oleh Syaban (2009: 128 ) mengemukakan pada saat ini, daya dan disposisi siswa belum tercapai sepenuhnya.Guru yang dapat mengembangkan kemampuan berpikir siswanya ini dapat dikatakan sebagai guru yang efektif. Menurut Rusefendi (Bambang,2006:5) guru yang efektif akan lebih banyak mengajukan pertanyaan-pertanyaan kepada siswa. Pengajuan pertanyaan ini akan berdampak kepada pengembangan kemampuan berpikir siswa. Dalam mengembangkan kemampuan berpikir dan disposisi kritis, seorang guru perlu melakukan variasi dalam pembelajaran, misalnya menggunakan metode, pendekatan yang bervariasi sesuai dengan situasi siswa.

Menurut Schoenfeld (Nanang,2012) salah satu pendekatan pembelajaran yang dilandasi konstruksivisme dalam upaya meningkatkan proses kemampuan berpikir matematis siswa yang dapat mengedepankan bagaimana seharusnya siswa berpikir, dan bagaimana berpikir terbaik untuk dapat memecahkan permasalahan matematika adalah model pembelajaran metakognitif. Metakognitif merupakan keterampilan seseorang dalam mengatur dan mengontrol proses berpikirnya. Menurut teori metacognition (Iskandar,2014) bahwa siswa yang belajar memiliki keterampilan tertentu untuk mengatur dan mengontrol apa yang 
dipelajarinya. Keterampilan ini berbeda antara individu yang satu dengan individu yang lain sesuai dengan kemampuan proses berpikirnya. Keempat jenis keterampilan, yaitu: pemecahan masalah, pengambilan keputusan, berpikir kritis, dan berpikir kreatif.

Cristanti (2015) pendekatan metakognitif bertujuansalah satunya adalah untuk menumbuhkan kesadaran bertanya pada diri sendiri. Melalui pendekatan ini, siswa diajak untuk menyadari kekurangan serta kelebihan yang dimiliki-nya dalam mempelajari matematika serta bagai-mana mengatasinya. Pembelajaran dengan pen-dekatan ini cenderung lebih banyak melibatkan siswa secara aktif sebagai pusat pembelajaran dibanding pembelajaran ekspositori. Siswa tidak lagi menjadi objek pasif di dalam kelas. Melainkan secara aktif mengontrol proses ber-pikir dan belajarnya. Melalaui Pendekatan ini matematika juga disajikan sebagai suatu kegiatan berpikir dan bernalar, bukan sebagai penanaman konsep-konsep abs-trak. Kegiatan yang lebih bervariasi inilah yang kemudian diduga berpotensi untuk mengatasi masalah kemampuan berpikir kritis matematis.

Menurut Noto (2016) pendekatan metakognitif ini membantu siswa untuk menuangkan hasil pemikiran siswa sesuai dengan kemampuan yang mereka miliki sehingga dapat membangun kemampuan berpikir dan disposisi kritis matematis siswa itu sendiri. Pendekatan ini menawarkan langkah-langkah yang sejalan dengan indikator berpikir reflektif matematis. Dalam pendekatan metakognitif, siswa disadarkan untuk mengontrol dan memantau proses berpikirnya melalui: pengajuan pertanyaan tentang pemahaman masalah; membangun koneksi antara pengetahuan baru dan pengetahuan sebelumnya; menggunakan strategi penyelesaian masalah; mengevaluasi proses dan solusiberpikirnya.

Selain memperhatikan kemampuan dan disposisi berpikir kritis, kita sebagai guru perlu bertanggung jawab pada tahap perkembangan kognitif siswa di sekolah. Dimana perkembangan kognitif merupakan salah satu aspek yang sangat penting dalam perkembangan pesertadidik. Sesuai dengan teori piaget pemahaman seseorang mengalami perkembangan dari lahir sampai menjadi dewasa (Mutamam,2017). Piaget meyakini bahwa perkembangan kognitif seseorang terjadi dalam empat tahapan, yakni sensorimotor, praoperasional, operasi konret, dan operasi formal. Tiap-tiap tahapan berkaitan dengan usia dan tersusun dari jalan pikiran yang berbeda-beda. Menurut Piaget semakin banyak informasi tidak membuat pikiran anak lebih maju. Kulitas kemajuannya beda-beda.

Berdasarkan tahapan Piaget, usia SMA seharusnya sudah memasuki tahap operasi formal tetapipada kenyataannya di sekolah yang saya teliti ada beberapa siswa SMA yang masih pada tahap opersi konkret. Seperti yang dikatakan Rusefendi (Mutammam,2017) 
bahwa masih terdapat peserta didik yang telah lulus jenjang sekolahmenengah juga mahasiswa tidak pernah mencapai penalaran formal. Penulis ingin menggunakan tes yang bisa mengukur anak berada pada tahap formal,transisi atau kongkret. Dalam hal ini penulis menggunakan Tes of Logical Thinking (TOLT), yang dikembangkan oleh Tobin \& Capie (1981).

Beberapa peneletian yang relevan yaitu Cristanti (2015), Nindiasari (2013), Muin (2016), Bambang (2015) menyatakan bahwa pendekatan metakognitif adalah pendekatan yang cukup efektif untuk mengembangkan berbagai kemampuan berpikir matematis maupun berbagai soft skills dalam pembelajaran matematika.Penelitian-penelitian yang berkaitan dengan pendekatan metakognitif yang sudah dilakukan tersebut mengukur berbagai kemampuan berpiki matematis dan kemampuan tersebut meningkat namun belum ada yang di tinjau dari tahap perkembangan kognitif.

\section{METODE PENELITIAN}

Penelitian ini menggunakan desain kuasi eksperimen. Untuk itu diberikan kelas eksperimen dan kelas kontrol. Setelah diberikan perlakuan, perubahannya diukur untuk mengetahui ada tidaknya perubahan dan mengetahui bagaimana variabel yang diteliti. Desain eksperimen yang dipilih adalah treatment by level $2 \times 3$. Setelah diberikannya perlakuan (treatment), maka guru memberikan post response dalam bentuk test kemampuan berpikir kritis matematis dan disposisi kritis siswa tujuannya ialah untuk membandingkan hasil akhir yang diperoleh kedua kelas, baik kelas eksperimen maupun kelas kontrol. Agar lebih mudah melihat perbedaan perlakuan kelas eksperimen dan kelas kontrol, dapat dilihat pada desain rencana perlakuan terhadap sampel penelitian.

\section{HASIL DAN PEMBAHASAN}

Pengolahan data kuantitatif dilakukan dengan menggunakan bantuan softwareSPSS versi 22.0 for Windows. Data diperoleh dari 65 orang siswa kelas XI salah satu SMA di Pandeglang, dengan 34 orang siswa di kelompok eksperimen dan 31 orang siswa di kelompok kontrol. Data yang dianalisis adalah data perkembangan kognitif diperoleh dari instrument yang dibuat oleh tobin $n$ capie. Sedangkan data kemampuan berpikir kritis siswa diperoleh dari data pretes dan postes untuk melihat peningkatan masing-masing kelas, serta data $N$-gain disposisi kritis siswa digunakan untuk melihat peningkatan disposisi kritis siswa setelah siswa belajar dengan pembelajaran pendekatan metakognitif dan pembelajaran ekspositori.

Prima, Vol. 3, No. 2, Juli 2019, 134-145. 
Tabel 1. Sebaran sampel penelitian

\begin{tabular}{lccc}
\hline $\begin{array}{l}\text { Tahap Perkembangan } \\
\text { Kognitif Siswa }\end{array}$ & $\begin{array}{l}\text { Kelas } \\
\text { Pendekatan } \\
\text { metakognitif }\end{array}$ & Ekspositori & Total \\
\hline Formal & 12 & 8 & 20 \\
Transisi & 8 & 12 & 20 \\
Konkret & 14 & 11 & 25 \\
Total & 34 & 31 & 65 \\
\hline
\end{tabular}

Pada pelaksanaan pretes siswa diminta untuk mengerjakan paket soal yang sama, dimana pretes dilaksanakan di awal penelitian sedangkan postes dilaksanakan setelah penelitian. Berdasarkan hasil kedua tes tersebut (pre tes dan post tes). Pretes dilaksanakan pada tanggal 11 November 2018 di kelas eksperimen dan control. Sedangkan postes dilakukan pada tanggal 10 desember. Soal pretes terdiri dari 5 soal berpikir kritis yang diberikan kepada siswa untuk dilihat dampak penggunaan pendekatan metakognitif terhadap kemampuan berpikir kritis matematis melalui nilai $N$-gain yang diperoleh sampel penelitian. Berikut akan disajikan statistik deskriptif skor pretes, postes, dan $N$-gain kemampuan berpikir kritis matematis siswa. Perhitungan selengkapnya dapat dilihat pada lampiran.

Tabel 2. Statistik Deskriptif Kemampuan Brpikir kritis Matematis Siswa

\begin{tabular}{|c|c|c|c|c|c|c|c|}
\hline \multirow{2}{*}{$\begin{array}{l}\text { Tahap Kognitif } \\
\text { Siswa }\end{array}$} & \multirow{2}{*}{ Data } & \multicolumn{3}{|c|}{ Metakognitif } & \multicolumn{3}{|c|}{ Ekspositori } \\
\hline & & Pretes & Postes & $N$-gain & Pretes & Postes & N-gain \\
\hline \multirow{5}{*}{ Formal } & $\mathbf{N}$ & 12 & & & 8 & & \\
\hline & Min & 15 & 70 & 0,54 & 15 & 60 & 0,38 \\
\hline & $\operatorname{Max}$ & 35 & 95 & 0,93 & 35 & 85 & 0,77 \\
\hline & $\bar{x}$ & 24,16 & 77,92 & 0,70 & 24,16 & 71,25 & 0,69 \\
\hline & SD & 7,6 & 7,5 & 0,107 & 7,6 & 9,161 & 0,12 \\
\hline \multirow{5}{*}{ Transisi } & $\mathbf{N}$ & 8 & & & 12 & & \\
\hline & Min & 5 & 55 & 0,36 & 5 & 55 & 0,40 \\
\hline & Max & 40 & 95 & 0,93 & 30 & 75 & 0,69 \\
\hline & $\bar{x}$ & 21,25 & 75 & 0,67 & 21,25 & 66,67 & 0,6188 \\
\hline & SD & 7,44 & 11,9 & 0,170 & 7,44 & 6,853 & 0,13 \\
\hline \multirow{5}{*}{ Konkret } & $\mathbf{N}$ & 14 & & & 11 & & \\
\hline & Min & 5 & 65 & 0,5 & 5 & 55 & 0,40 \\
\hline & Max & 40 & 90 & 0,88 & 30 & 80 & 0,71 \\
\hline & $\bar{x}$ & 21,42 & 75,71 & 0,68 & 21,42 & 64,55 & 0,577 \\
\hline & SD & 7,10 & 8,05 & 0,110 & 7,10 & 7,891 & 0,106 \\
\hline \multirow{5}{*}{ Seluruh } & $\mathbf{N}$ & 34 & & & 31 & & \\
\hline & Min & 5 & 55 & 0,93 & 5 & 55 & 0,58 \\
\hline & $\operatorname{Max}$ & 40 & 95 & 0,36 & 35 & 85 & 0,77 \\
\hline & $\bar{x}$ & 22,35 & 76 & 0,69 & 22.35 & 67,10 & 0,58 \\
\hline & SD & 8,98 & 8,731 & 0,12 & 8,98 & 8,039 & 0,10 \\
\hline
\end{tabular}

Skor Maksimum Ideal Pretes dan Postes adalah 100 Skor Maksimum Ideal N-gain adalah 1 


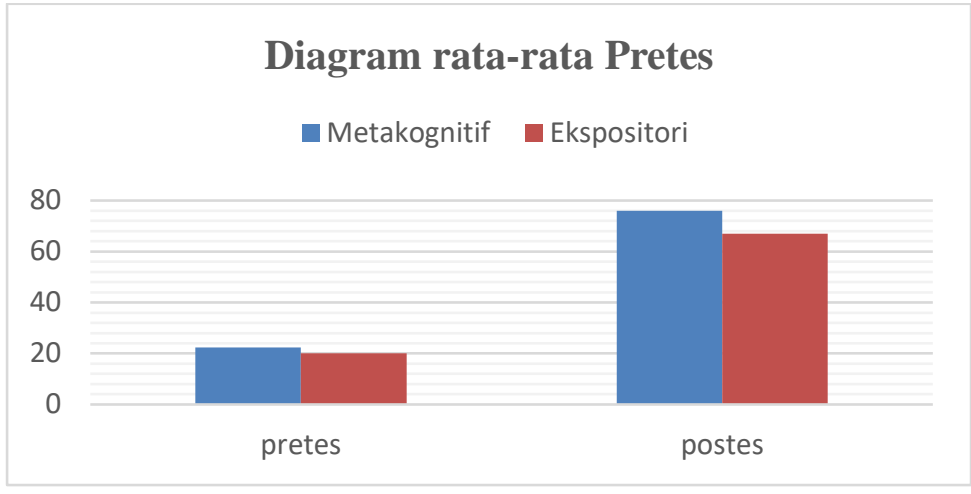

Gambar 1. Rata-rata pretes dan postess

Berdasarkan diagram batang di atas dapat dilihat bahwa tinggi batang yang menunjukan nilai rata-rata pretes kelas eksperimen relatif sama dengan nilai rata-rata pretes kelas kontrol. Dari analisis statistic deskriptif baik berupa tabel maupun berupa diagram. Atau dengan kata lain, kemampuan awal siswa antara kelas eksperimen dan kontrol relatif sama.

Rataan nilai $\mathrm{N}$-gain pada kelas yang menggunakan pendekatan metakognitif dan kelas yang mendapatkan pendekatan ekspositori adalah sebesar 0,69 dan 0,58. Perbedaan rata-rata disajikan melalui diagram batang pada gambar berikut ini:

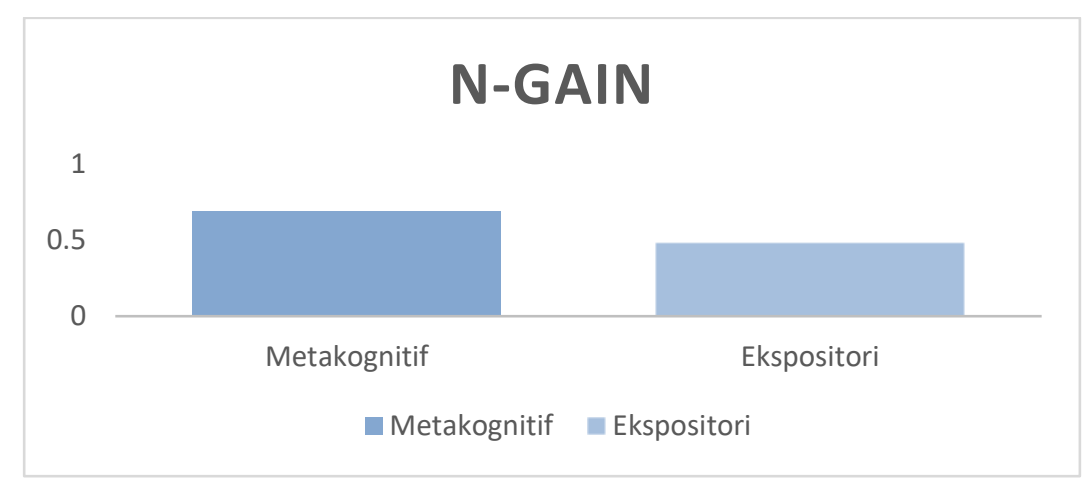

Gambar 2. Rata-rata N-gain

Berdasarkan gambar di atas rerata N-gain kemampuan berpikir kritis pada kelas eksperimen lebih tinggi daripada kelas kontrol dengan selisih 0,11. Untuk mempermudah melihat perbedaan rerata $\mathrm{N}$-gain ditinjau dari tahap perkembangan kognitif maka perhatikan gambar di bawah ini 


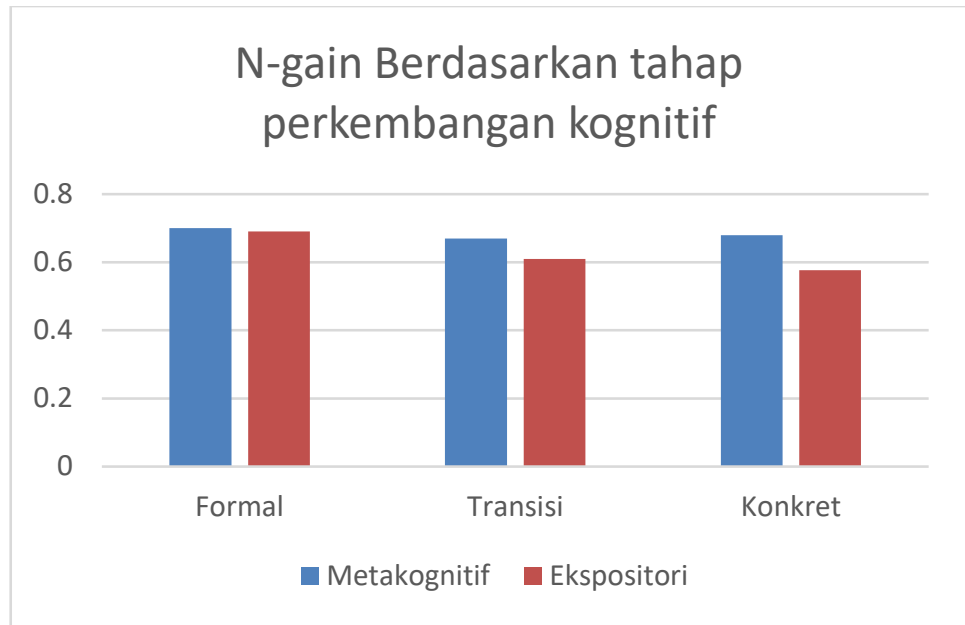

Gambar 3. Rata-rata N-gain ditinjau dari tahap perkembangan Kognitif

Berdasarkan diagram batang di atas, Rerata N-gain tiap tahap perkembangan kognitif lebih besar. Pada tahap formal selisih N-gain pada kelas eksperimen dan kelas kontrol hanya 0.01, sedangkan pada tahap transisi selisih $\mathrm{N}$-gain pada kelas eksperimen dengan kelas kontrol yaitu 0,07. Pada tahap konkret selisih $\mathrm{N}$-gain antara kelas eksperimen dengan kelas kontrol yaitu 0.11 .

Berikut adalah hasil output dari uji hipotesis dengan SPSS 22.0 for windows

Tabel 3. Tests of Between-Subjects Effects

\begin{tabular}{|c|c|c|c|c|c|}
\hline Source & $\begin{array}{l}\text { pe III Sun } \\
\text { Squares }\end{array}$ & df & Mean Square & $\mathbf{F}$ & Sig. \\
\hline Corrected Model & $.197^{\mathrm{a}}$ & 5 & .039 & 2.891 & .021 \\
\hline Intercept & 25.437 & 1 & 25.437 & 1865.552 & .000 \\
\hline Metode & .159 & 1 & .159 & 11.658 & .001 \\
\hline Kognitif & .017 & 2 & .008 & 610 & .547 \\
\hline metode $*$ kognitif & .002 & 2 & .001 & .060 & .942 \\
\hline Error & .804 & 59 & .014 & & \\
\hline Total & 27.702 & 65 & & & \\
\hline Corrected Total & 1.002 & 64 & & & \\
\hline
\end{tabular}

a. Nilai P-value untuk model pembelajaran dengan nilai Sig lebih kecil dari $\alpha$, maka $\mathrm{H}_{0}$ ditolak. Dengan nilai Sig model pembelajaran adalah 0,000, maka $0.001>0.05$. Sehingga disimpulkan Peningkatan kemampuan berpikir kritis matematis siswa yang memperoleh pembelajaran pendekatan metakognitif lebih tinggi daripada siswa yang memperoleh pembelajaran ekspositori 
b. Nilai P-value untuk pembelajaran * kognitif dengan nilai Sig lebih besar dari $\alpha$, maka $\mathrm{H}_{0}$ diterima. Dengan nilai sig Kognitif adalah 0,671, maka 0.671>0.05. Sehingga disimpulkan Tidak terdapat pengaruh interaksi antara pembelajaran pendekatan metakognitif dan tahapan perkembangan kognitif terhadap kemampuan berpikir kritis matematis siswa.

\section{SIMPULAN DAN SARAN}

\section{Simpulan}

Berdasarkan hasil penelitian penerapan pendekatan metakognitif untuk meningkatkan kemampuan berpikir matematis dan disposisi kritis matematika siswa SMA ditinjau dari tahap perkembangan kognitif. Diperoleh kesimpulan sebagai berikut:

1. Peningkatan kemampuan berpikir kritis matematis siswa yang memperoleh pembelajaran pendekatan metakognitif lebih tinggi siswa yang memperoleh pembelajaran ekspositori

2. Tidak terdapat pengaruh interaksi antara pembelajaran pendekatan metakognitif dan tahapan perkembangan kognitif terhadap kemampuan berpikir kritis matematis siswa

\section{Saran}

Berdasarkan kesimpulan dan implikasi di atas, diajukan beberapa rekomendasi sebagai berikut.

1. Sebaiknya pembelajaran pendekatan metakognitif dijadikan sebagai salah satu alternatif pembelajaran di kelas karena pembelajaran pembelajaran metakognitif dapat menumbuhkan kemampuan berpikir dan disposisi kritis siswa.

2. Materi yang dikembangkan peneliti hanya materi persamaan barisan dan deret, sebaiknya bagi peneliti lain untuk lebih mengeksplor dengan materi matematika lain.

3. Perlu dilakukan penelitian lanjutan dengan memperhatikan tingkat kemampuan siswa maupun jenjang pendidikan.

\section{DAFTAR PUSTAKA}

Arikunto, Suharsimi. (2013). Prosedur Penelitian Suatu Pendekatan Praktik. Jakarta: Rineka Cipta

Ahmadi, yusuf. (2016). Analisis Kemampuan Berpikir kritis matematis siswa pada materi Segitiga. Jakarta. Skripsi UIN

Prima, Vol. 3, No. 2, Juli 2019, 134-145. 
Creswell, J.W. (2010). Research design; pendekatan kualitatif,kuantitatif, dan mixed. Yogyakarta : PT Pustaka Pelajar.

Hendriana, dkk. (2017). Hard Skills dan soft skills. 2017.Bandung. Refika Aditama

Husnindar,dkk. (2014). Penerapan Model Pembelajaran Berbasis Masalah untuk meningkatkan kemampuan berpikir kritis dan disposiss matematis.jurnal didaktik matematika universitas Syiah Kuala banda aceh.

Karim, Asrul.(2011). Peerapan metode penemuan terbimbing dalam pembelajaran matematika untuk meningkatkan pemahaman konsep dan kemampuan berpikir krutis siswa sekolah dasar.

Kemendikbud. (2013). Permendikbud No. 54 tentang Standar Kompetensi Lulusan Pendidikan Dasar dan Menengah. Jakarta; Kementrian Pendidikan dan Kebudayaan

Lestari,K.E, \& Yudhanegara, M. (2015). Penelitian Pendidikan Matematika. Bandung : PT Refika Aditama.

Lestari, I. (2016). Kemampuan Representasi dan Self Confidence Siswa sma Melalui Strategi Thinking Aloud Pair Probelm Solving (Tapps) Berbatuan Geogebra. Tesis . UPI:Tidak diterbitkan.

Maulana (2008). Pendekatan metakognitif sebagai alternatif pembelajaran Matematika untuk meningkatkan kemampuan Berpikir Kritis Matematika PGSD. Jurnal Pendidikan Dasar.

M.Iskanda (2014). Pendekatan Keterampilan Metakognitif. Fmipa Malang Vol 2

Muin, Abdul ( 2016). Meningkatkan kemampuan dan disposisi Berpikir Reflektif Matematis Mahasiswa Dengan Pendekatan Metakognitif. Tesis UPI

Murni, Atma (2010). Pembelajaran matematika dengan pendekatan metakognitif bebrbasisi masalah konstektual. FKIP Universitas Riau.

Mutamammam.Pemetaan Perkembangan Kognitif Piaget Siswa SMA Menggunakan Tes Operasi Logis (TOL) Piaget Ditinjau Dari Perbedaan Jenis Kelamin.Jurnal Universitas Negeri Surabaya.

Nindiasari, Hepsi (2013). Meningkatkan Kemampuan Dan Disposisi Berpikir Reflektif Matematis Serta Kemandirian Belajar Siswa Melalui Pembelajaran dengan Pendekatan Metakognitif. Disertasi UPI. Tidak diterbitkan.

Prof. Dr. Sugiyono, (2017). Metode Penelitian Kuantitatif, Kualitatif, dan R\&D, Bandung :Alfabeta.

Rasiman. Meningkatkan kemampuan berpikir kritis melalui pembelajaran matematika dengan pendekatan realistik . Jurnal IKIP PPGRI Semarang. 
Riduwan.(2012). Dasar-dasar Statistika. Bandung : Alfabeta.

Ruseffendi, E. T. (2005). Dasar-dasar Penelitian Pendidikan dan Bidang Non Eksakta Lainnya. Bandung: Tarsito.

Sa'adah,dkk. (2017). Pengembangan perangkat ajar model core pendekatan metakognitif untuk meningkatkan kemampuan pemecahan masalah geometri kelas VIII. Jurnal Edumath.

Sabandar, josua. Berpikir reflektif dalam pembelajaran matematika. Jakarta : Universitas Pendidikan Indonesia.

Saparudin. (2013). Pemecahan masalah matematika sebagai sarana mengembangkan penalaran formal siswa sekolah menengah pertama. Jurnal Sainsmat.

Srianggoro, Bambang (2014).Mengembangkan Kemampuan Berpikir Kritis Dan Disposisi Matematis Siswa Melalui Metode Pembelajaran Improve. Disertasi UPI. Tidak diterbitkan.

Suherman, Erman dkk. (2001). Strategi Pembelajaran Kontemporer. Bandung;Jica.

Suherman, Erman dkk. (2001). Evaluasi Proses Dan Hasil Belajar Matematika. Bandung:Jica.

Sumarmo , Utari. (2013) Berpikir dan Disposisi matematis serta Pembelajrannya. FMIPA UPI Bandung.

Sumarmo, Utari. (2010). Berpikir dan Disposisi Matematik: Apa, Mengapa, dan Bagaimana Dikembangkan Pada Peserta Didik. FMIPA UPI Bandung.

Sumarmo, dkk. (2011). Kemampuan Dan Disposisi Berpikir Logis, Kritis, dan Kreatif Matematik. FMIPA UPI Bandung.

Sumarmo, U. (2012). Pendidikan karakter Serta Pengembangan Berfikir Dan Disposisi Matemati Dalam Pembelajaran Matematika.Makalah dalam seminar nasioanl NTT.

Sumaryati, Enung. (2013). Pendekatan Induktif Deduktif Disertai Strategi Think-PairSquare_Share untuk meningkatkan kemampuan pemahaman dan berpikir kritis serta disposisi matematis siswa SMA. Jurnal STKIP Siliwangi Bandung.

Sugiyono. (2013). Statistik untuk penenlitian Bandung: Alfabeta.

Sulystiani Eni. (2016). Pentingnya Berpikir Kritis dalam Pembelajaran Matematika untuk Menghadapi Tantangan MEA. Seminar Nasional Matematika X Universitas Negeri Semarang.

Sukenda Asep. (2016). Kemampuan berpikir kritis dan Kemandirian belajar dengan hasil belajar mtematika. Jurnal Pendidikan Dasar.

Prima, Vol. 3, No. 2, Juli 2019, 134-145. 
Tobin, G., \& Capie, W. (1981). The best of lagical thingkin. SAGE Publication 413-424 . Retrieved From hhtps:www.researchgate.net/publication/234585889

Trifone, J.D. (1987). The best of Logical Thingking. The American Biology Teacher, 49 (8), 411-416. 